\title{
PENGUKURAN KUALITAS PELAYANAN BLENGER BURGER
}

\section{SERVICE QUALITY MEASUREMENT AT BURGER BLENGER}

\author{
Nurjannah $^{1}$ dan Aulady Shoyfi ${ }^{2}$ \\ ${ }^{1}$ Program Studi Teknik Industri, Fakultas Teknik, Universitas Gunadarma, Jl. Margonda Raya No. 100, \\ Pondok Cina, Depok, Jawa Barat Email : nurjannah@staff.gunadarma.ac.id \\ ${ }^{2}$ Program Studi Teknik Industri, Fakultas Teknik, Universitas Gunadarma, Jl. Margonda Raya No. 100, \\ Pondok Cina, Depok, Jawa Barat Email : auladyshoyfi@student.gunadarma.ac.id
}

\begin{abstract}
ABSTRAK
Kualitas pelayanan menjadi salah satu syarat kelangsungan hidup dari suatu perusahaan atau instansi, tingginya kualitas pelayanan yang diberikan akan tercermin pada aspek kepuasan pengguna jasa. Penelitian ini dilakukan dengan tujuan untuk mengukur kualitas pelayanan diblenger burger berdasarkan persepsi dan harapan konsumen. Pengukuran kualitas pelayanan di blenger burger terhadap kepuasan konsumen berdasarkan lima dimensi kualitas pelayanan, yaitu : tangible memiliki nilai gap sebesar $-0,66$, realibility memiliki nilai gap sebesar $-0,61$, responsiveness memiliki nilai gap sebesar -0,66, empathy memiliki nilai gap sebesar -0,58, dan assurance memiliki nilai gap sebesar -0,58. Berdasarkan Importance Performance Analysis (IPA) bahwa tingkat kualitas pelayanan di blenger burger terhadap kepuasaan konsumen berdasarkan tingkat kinerjanya yaitu ketanggapan pelayan terhadap konsumen. Hasil perhitungan dari customer satisfaction index (CSI) mengenai kualitas pelayanan berdasarkan persepsi konsumen diblenger burger, yaitu sebesar 76,39 dimana nilai tersebut menunjukkan menurut kriteria nilai customer statisfaction index (CSI) adalah puas.
\end{abstract}

Kata Kunci: Service Quality (servqual), Importance Performance Analysis (IPA), Customer Statisfaction Index (CSI).

\begin{abstract}
Service quality becomes one of the survival requirements of a company or agency, the high quality of service provided will be reflected in the aspect of service user satisfaction. The study was conducted with the aim of measuring the quality of burger diblenger service based on consumer perceptions and expectations. Measurement of service quality in blenger burger to consumer satisfaction based on five dimensions of service quality, namely: tangible has a gap value of -0.66, realibility has a gap value of -0.61 , responsiveness has a gap value of -0.66 , empathy has a gap value of -0.58 , and assurance has a gap value of -0.58. Based on Importance Performance Analysis (IPA) that the level of service quality in the burger blenger to consumer satisfaction based on the level of performance is the responsiveness of the waiter to the consumer. The results of calculations from the customer satisfaction index (CSI) regarding the quality of service based on consumer perception diblenger burger, which is 76.39 where the value indicates according to the criteria the value of customer statisfaction index (CSI) is satisfied.
\end{abstract}

Keywords: Service Quality (servqual), Importance Performance Analysis (IPA), Customer Statisfaction Index (CSI). 


\section{Pendahuluan}

Pada perkembangan di dunia industri makanan, setiap restoran yang menyediakan makanan cepat saji dituntut untuk mampu memenuhi kepuasan konsumen baik dalam hal rasa, harga, maupun kualitas pelayanannya. Menurut Ninemeier dan Hayes (2011) mengemukakan bahwa restoran merupakan suatu operasional pelayanan makanan yang menghasilkan keuntungan yang mana basis utamanya termasuk di dalamnya adalah penjualan makanan atau minuman kepada orang-orang dan tamu-tamu dalam kelompok kecil. Menurut Tjiptono (2014), kualitas pelayanan merupakan ukuran seberapa bagus tingkat layanan yang diberikan mampu sesuai dengan ekspektasi pelanggan. Sehingga kualitas pelayanan menjadi salah satu syarat kelangsungan hidup dari suatu perusahaan atau instansi, tingginya kualitas pelayanan yang diberikan akan tercermin pada aspek kepuasan pengguna jasa. Banyaknya usaha-usaha makanan maupun minuman yang bermunculan dalam bentuk waralaba atau franchise membuat persaingan bisnis antar restoran makanan berlomba-lomba untuk meningkatkan kualitas pelayanannya sehingga dapat memberikan kepuasan terhadap konsumennya.

Blenger Burger merupakan salah satu jenis usaha makanan (restoran) yang memiliki berbagai macam jenis produk yang dihasilkan, seperti burger, hotdog, sosis, dan juga kentang gorengnya. Blenger Burger memiliki ciri khasnya tersendiri dibandingkan burger-burger lainnya, yaitu dilihat dari ukuran burgernya yang lebih besar dibandingkan ukuran burgerburger pada umumnya. Blenger Burger adalah salah satu restauran cepat saji yang menerapkan sistem pelayanan yang ramah terhadap konsumen seperti menyajikan pesanan makanan dengan cepat dan membantu mendekskripsikan menu-menu makanan yang disajikan. Tetapi, dari sistem pelayanan yang diterapkan oleh blenger burger belum tentu telah sesuai dengan keinginan dan harapan oleh konsumen sehingga perlu dilakukannya penelitian terkait kualitas pelayanan yang telah diterapkan oleh blenger burger telah memenuhi keinginan dan harapan konsumen atau belum memenuhi sesuai dengan standar yang diinginkan oleh konsumen.

Kepuasaan konsumen merupakan salah satu hal yang sangat penting bagi perusahaan maupun restoran karena jika perusahaan atau restoran dapat mencapai kepuasaan konsumen maka perusahaan maupun restoran dapat meningkatkan pangsa pasar. Metode Servqual (Service Quality) merupakan salah satu metode yang digunakan untuk mengukur kualitas pelayanan sehingga metode ini memiliki manfaat dibandingkan metode-metode lainnya yaitu metode servqual dapat mengukur kualitas jasa yang dirasakan oleh para konsumen yang dilihat dari lima dimensi kualitas yaitu kehandalan (reliability), jaminan (assurance), bentuk fisik (tangible), empati (empathy) dan daya tanggap (responsivennes) dengan memberikan analisa kesenjangan terhadap (gap) yang terjadi akibat ketidaksesuaian antara harapan dengan persepsi konsumen terhadap kualitas pelayanan yang diterimanya (Tjiptono, 2014).

Analisis kualitas pelayanan terhadap konsumen dengan menggunakan metode service quality di blenger burger sangat dibutuhkan oleh restoran dengan harapan untuk meningkatkan kualitas pelayanan dari blenger burger. Selain itu meminimasi gap antara keinginan dan harapan konsumen dan dapat memberikan evaluasi bagi perusahaan dengan menentukan strategi dalam meningkatkan kualitas pelayanan dan kepuasan konsumen.

Tujuan dari penelitian ini antara lain yaitu mengukur kualitas pelayanan yang dilakukan oleh restoran blenger burger. Selain itu, juga mengukur kepuasan pelanggan atas pelayanan yang sudah diberikan oleh restoran. 


\section{Metodologi Penelitian}

Urutan proses penelitian dapat dilihat pada Gambar 1 diagram alir penelitian berikut ini.

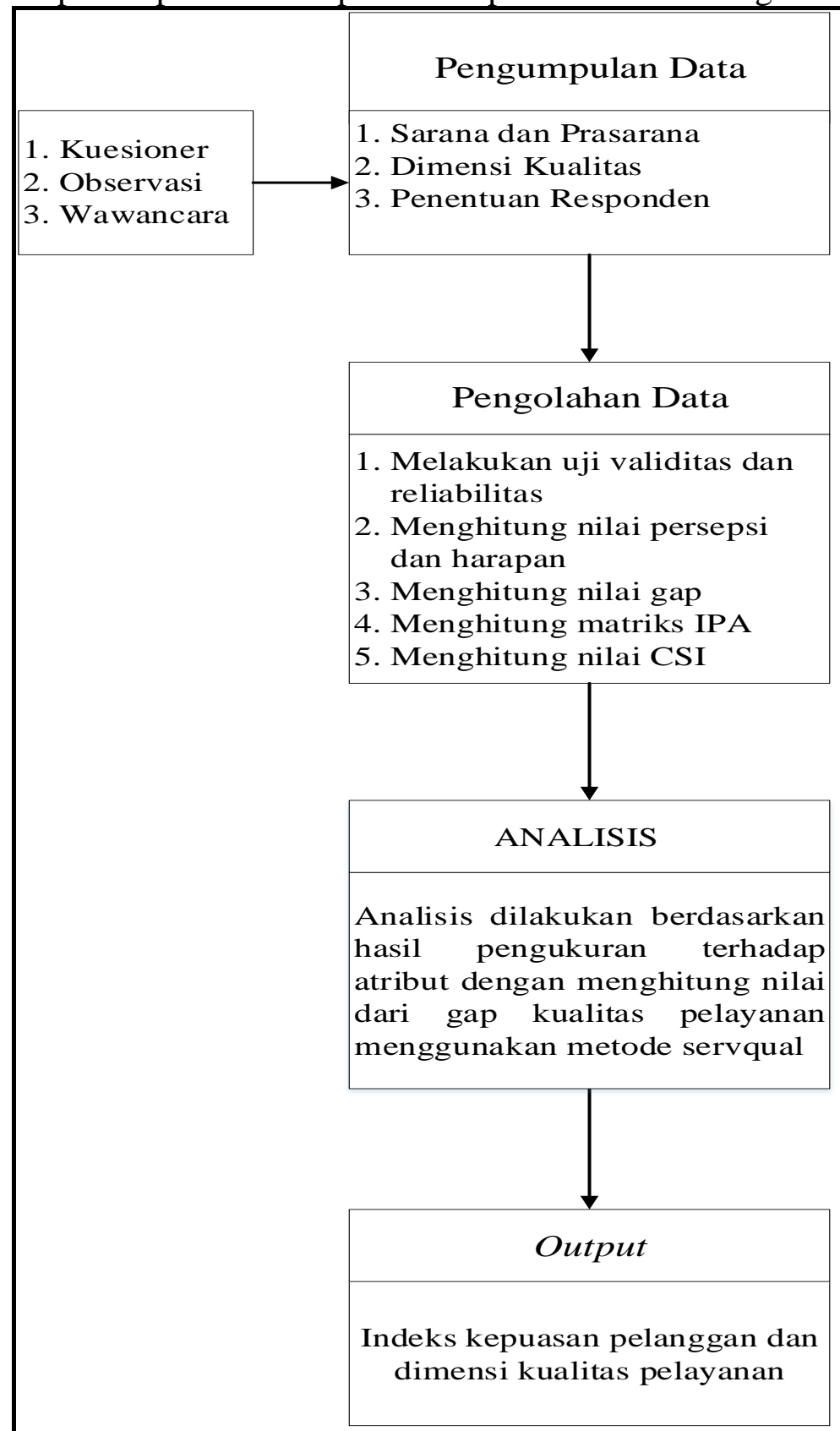

Gambar 1 Metodologi Penelitian

\section{Hasil Dan Pembahasan}

\subsection{Persepsi dan Harapan}

Kotler dan Keller (2011) mendefinisikan persepsi adalah proses bagaimana seseorang menyeleksi, mengatur dan mengintepretasikan masukan informasi untuk menciptakan gambaran umum keseluruhan yang berarti. Harapan menurut Tjiptono (2011) merupakan 
perkiraan atau keyakinan pelanggan tentang apa yang akan diterimanya. Harapan konsumen merupakan tolok ukur dalam menentukan kualitas suatu produk. Berikut ini merupakan tabel tingkat kesesuaian dari persepsi dan harapan konsumen terhadap blenger burger

Tabel 1 Tingkat Penilaian Pernyataan Persepsi dan Harapan

\begin{tabular}{|c|c|c|c|c|}
\hline $\begin{array}{l}\text { No. } \\
\text { pernyataan }\end{array}$ & $\begin{array}{l}\text { Skor } \\
\text { persepsi }\end{array}$ & $\begin{array}{l}\text { Tingkat } \\
\text { persepsi } \\
\text { (Xi) }\end{array}$ & $\begin{array}{l}\text { Skor } \\
\text { harapan }\end{array}$ & $\begin{array}{l}\text { Tingkat } \\
\text { Harapan } \\
\text { (Yi) }\end{array}$ \\
\hline 1 & 373 & 3,73 & 431 & 4,31 \\
\hline 2 & 375 & 3,75 & 426 & 4,26 \\
\hline 3 & 391 & 3,91 & 440 & 4,4 \\
\hline 4 & 359 & 3,59 & 425 & 4,25 \\
\hline 5 & 387 & 3,87 & 439 & 4,39 \\
\hline 6 & 386 & 3,86 & 433 & 4,33 \\
\hline 7 & 372 & 3,72 & 426 & 4,26 \\
\hline 8 & 398 & 3,98 & 439 & 4,39 \\
\hline 9 & 382 & 3,82 & 440 & 4,4 \\
\hline 10 & 384 & 3,84 & 445 & 4,45 \\
\hline 11 & 377 & 3,77 & 436 & 4,36 \\
\hline 12 & 373 & 3,73 & 436 & 4,31 \\
\hline 13 & 383 & 3,83 & 436 & 4,39 \\
\hline 14 & 372 & 3,72 & 436 & 4,38 \\
\hline 15 & 393 & 3,93 & 441 & 4,41 \\
\hline 16 & 373 & 3,73 & 431 & 4,31 \\
\hline 17 & 386 & 3,86 & 436 & 4,36 \\
\hline 18 & 380 & 3,8 & 429 & 4,29 \\
\hline 19 & 392 & 3,92 & 446 & 4,46 \\
\hline 20 & 382 & 3,82 & 440 & 4,4 \\
\hline 21 & 387 & 3,87 & 439 & 4,39 \\
\hline 22 & 398 & 3,98 & 446 & 4,46 \\
\hline Total & 8403 & 84,03 & 9596 & 95,96 \\
\hline
\end{tabular}

Pada tabel diatas dapat diketahui nilai-nilai dari masing-masing skor total berdasarkan persepsi dan harapan konsumen, nilai-nilai tersebut bertujuan untuk mengetahui rata-rata dari jumlah keseluruhan responden yang memiliki penilaiannya masing-masing berdasarkan dimensi kualitasnya sehingga dari perhitungan tersebut kita dapat menentukan gap dari tiaptiap atribut dimensi kualitasnya.

Dalam melakukan pengukuran sebagai acuan untuk mengolah data sehingga kita dapat mengetahui nilai dari gap atau kesenjangan yang terdiri dari persepsi dan harapan sesuai dengan dimensi kualitasnya berdasarkan responden terhadap kuesioner yang telah disebarkan di blenger burger ini. Berikut ini merupakan tabel rangkuman hasil nilai berupa gap yang terdiri dari persepsi dan harapan berdasarkan dimensi kualitasnya.

Tabel 2 Rangkuman Hasil Nilai Gap Persepsi dan harapan

\begin{tabular}{||l|l|c|c|c|c|c||}
\hline \multirow{2}{*}{ N0 } & \multirow{2}{*}{ Dimensi } & \multicolumn{2}{|c|}{ Persepsi } & \multicolumn{2}{c|}{ Harapan } & \multirow{2}{*}{ GAP } \\
\cline { 3 - 6 } & & Total & $\begin{array}{c}\text { Rata- } \\
\text { Rata }\end{array}$ & Total & $\begin{array}{c}\text { Rata- } \\
\text { Rata }\end{array}$ & \\
\hline 1. & Tangible & 1885 & 3,77 & 2161 & 4,322 & $-0,66$ \\
\hline 2. & Realibility & 1922 & 3,844 & 2183 & 4,37 & $-0,61$ \\
\hline 3. & Responsiveness & 1898 & 18,98 & 2185 & 21,85 & $-0,66$ \\
\hline 4. & Empathy & 1531 & 15,31 & 1742 & 17,42 & $-0,58$ \\
\hline 5. & Assurance & 1167 & 11,67 & 1325 & 13,25 & $-0,58$ \\
\hline
\end{tabular}


Pada tabel rangkuman hasil nilai gap persepsi dan harapan memberikan hasil dari perhitungan kuesioner untuk mengetahui nilai gap atau kesenjangan yang dilihat dari lima dimensi kualitas pelayanan yang memiliki nilai yang berbeda-beda. Pada dimensi tangible memiliki nilai gap sebesar -0,66 yang menujukkan bahwa pada dimensi ini memiliki kesenjangan antara persepsi dan harapan konsumen terhadap kualitas pelayanan di blenger burger. Kemudian pada dimensi realibility memiliki nilai gap sebesar -0,61 yang menunjukkan bahwa pada dimensi ini memiliki kesenjangan antara persepsi dan harapan konsumen terhadap kualitas pelayanan di blenger burger. Sehingga pada dimensi responsiveness memiliki nilai gap sebesar -0,66 yang menujukkan bahwa pada dimensi ini memiliki kesenjangan antara persepsi dan harapan konsumen terhadap kualitas pelayanan di blenger burger. Selanjutnya pada dimensi empathy memiliki nilai gap sebesar -0,58 yang menujukkan bahwa pada dimensi ini memiliki kesenjangan antara persepsi dan harapan konsumen terhadap kualitas pelayanan di blenger burger. Dimensi assurance memiliki nilai gap sebesar -0,58 yang menujukkan bahwa pada dimensi ini memiliki kesenjangan antara persepsi dan harapan konsumen terhadap kualitas pelayanan di blenger burger.

\subsection{Importance Performance Analysis (IPA)}

Metode Importance Performance Analysis (IPA) diperkenalkan oleh Martilla dan James (1977) untuk mengukur hubungan antara prioritas peningkatan produk atau jasa yang dikenal dengan quadrant analysis. IPA bertujuan untuk menampilkan informasi berkaitan dengan faktor-faktor pelayanan yang menurut pelanggan sangat mempengaruhi loyalitas dan kepuasan mereka. IPA menyatukan pengukuran faktor tingkat performansi (performance) dengan tingkat kepentingan (importance) yang digambarkan dalam diagram dua dimensi yaitu diagram importance-performance dimana sumbu x mewakili tingkat performansi sedangkan sumbu mewakili tingkat kepentingan. Berikut ini merupakan gambaran kuadran berdasarkan hasil nilai perhitungan kuesioner terhadap kualitas pelayanan blenger burger.

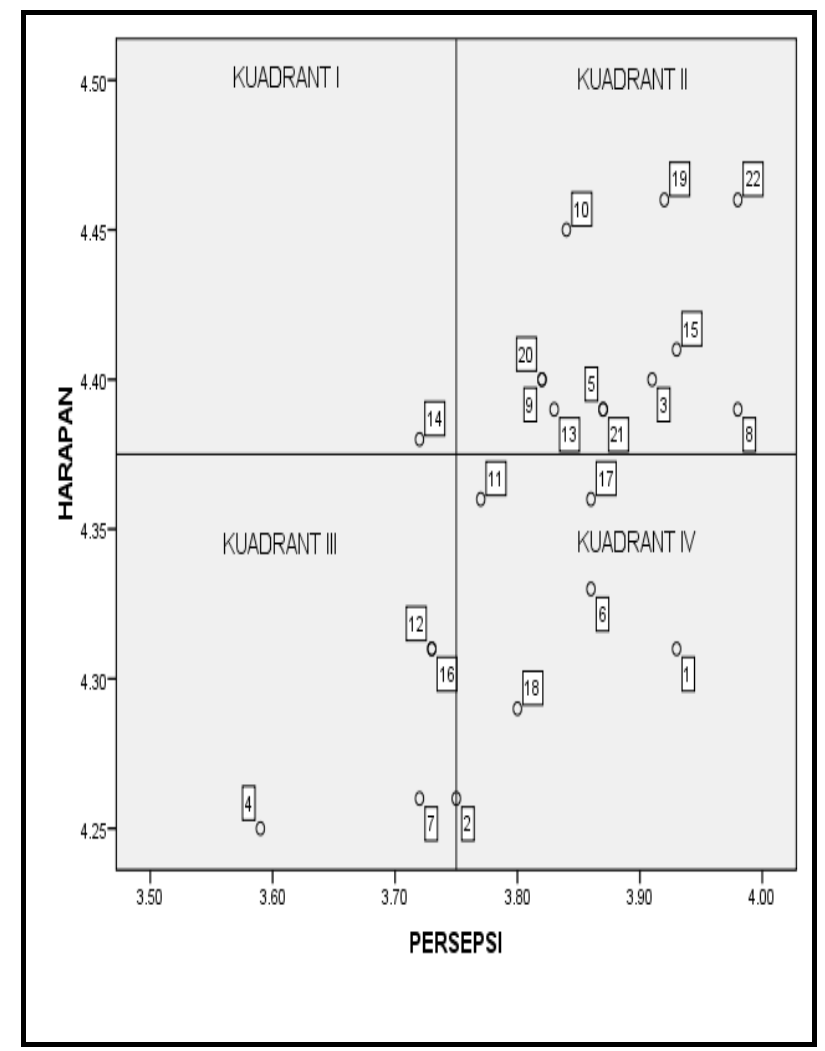


Berdasarkan hasil dari perhitungan kuesioner untuk mengetahui kualitas pelayanan yang terdapat diblenger burger berdasarkan persepsi dan harapan konsumen seperti yang terlihat pada Gambar 4.8 importance performance analysis, yaitu.

1) Kuadrant 1 : faktor-faktor yang mempengaruhi kualitas pelayanan diblenger Burger terdapat pada pernyataan nomor 14,dimana pada pernyataan nomor 14 ini mengenai ketanggapan pelayan terhadap konsumen. Pernyataan nomor 14 merupakan pernyataan yang memiliki peranan yang penting atau diharapkan oleh konsumen. Sehingga kondisi persepsi dan atau kinerja aktual yang ada pada saat ini belum memuaskan, oleh karena itu pihak manajemen dari restoran berkewajiban untuk meningkatkan kinerja terhadap pegawai-pegawainya agar dapat memberikan kepuasaan konsumen atas kualitas pelayanan yang diberikan baik.

2) Kuadrant 2 : faktor-faktor yang mempengaruhi kualitas pelayanan di blenger burger terdapat pada pernyataan nomor 20, 9, 13, 5, 21, 3,15, 8, 10, 19, 22. Faktor-faktor yang terletak pada pernyataan nomor yang berada di kuadran ini dianggap penting dan diharapkan sehingga menjadikan faktor penunjang bagi kepuasan konsumen. Oleh karena itu restoran blenger diharapkan dapat mempertahankan dan adanya peningkatan prestasinya didalam kualiatas pelayanan blenger burger.

3) Kuadrant 3 : faktor-faktor yang mempengaruhi kualitas pelayanan diblenger burger terdapat pada pernyataan nomor 12, 16, 7 dan 4. Faktor-faktor yang terletak pada pernyataan nomor yang berada di kuadran ini merupakan tingkat persepsi atau kinerja aktual yang rendah sekaligus dianggap tidak terlalu penting atau diharapkan oleh konsumen, sehingga restoran blenger burger tidak perlu terlalu memperhatikan faktorfaktor yang terdapat pada pernyataan nomor 12, 16, 7 dan 4 .

4) Kuadrant 4 : faktor-faktor yang mempengaruhi kualitas pelayanan diblenger burger terdapat pada pernyataan nomor $11,17,6,16$, dan 1 . faktor yang terletak pada pernyataan nomor yang berada di kuadran ini merupakan faktor dari penyataan kualitas pelayanan diblenger burger. Sehingga tidak memiliki faktor terlalu penting tetapi faktor-faktor tersebut perlu diperhatikan apakah salah satu dari faktor tersebut dapat ditingkatkan kinerjanya atau diberikan perbaikan dari pihak restorannya agar konsumen merasa puas terhadap kualitas pelayanan diblenger burger.

\subsection{Customer Statisfaction Index (CSI)}

Customer Satisfaction Index digunakan untuk mengukur tingkat kepuasan pelanggan terhadap kinerja pelayanan. Secara umum kepuasan atau ketidakpuasan konsumen merupakan hasil dari adanyaperbedaan-perbedaan antara harapan konsumen dengan kinerja yang dirasakan oleh konsumen tersebut menurut (Rangkuti, 2011). Berikut ini merupakan tabel hasil perhitungan kuesioner berdasarkan customer statisfaction index (CSI). 
Jurnal SEOI - Fakultas Teknik Universitas Sahid Jakarta

Vol 3 edisi 2 tahun 2021

Tabel 3 Hasil Perhitungan Customer Statisfaction Index (CSI)

\begin{tabular}{|c|c|c|c|c|}
\hline Kenyataan & $\begin{array}{c}\text { Jumlah } \\
\text { Responden }\end{array}$ & MIS & WF $(\%)$ & $\begin{array}{l}\text { WS } \\
(\%)\end{array}$ \\
\hline 373 & 100 & 3,73 & 4,44 & 16,95 \\
\hline 375 & 100 & 3,75 & 4,46 & 17,05 \\
\hline 391 & 100 & 3,91 & 4,65 & 17,77 \\
\hline 359 & 100 & 3,59 & 4,27 & 16,32 \\
\hline 387 & 100 & 3,87 & 4,61 & 17,59 \\
\hline 386 & 100 & 3,86 & 4,59 & 17,55 \\
\hline 372 & 100 & 3,72 & 4,43 & 16,91 \\
\hline 398 & 100 & 3,98 & 4,74 & 18,09 \\
\hline 382 & 100 & 3,82 & 4,55 & 17,36 \\
\hline 384 & 100 & 3,84 & 4,57 & 17,45 \\
\hline 377 & 100 & 3,77 & 4,49 & 17,14 \\
\hline 373 & 100 & 3,73 & 4,44 & 16,95 \\
\hline 383 & 100 & 3,83 & 4,56 & 17,41 \\
\hline 372 & 100 & 3,72 & 4,43 & 16,91 \\
\hline 393 & 100 & 3,93 & 4,68 & 17,86 \\
\hline 373 & 100 & 3,73 & 4,44 & 16,95 \\
\hline 386 & 100 & 3,86 & 4,59 & 17,55 \\
\hline 380 & 100 & 3,80 & 4,52 & 17,27 \\
\hline 392 & 100 & 3,92 & 4,67 & 17,82 \\
\hline 382 & 100 & 3,82 & 4,55 & 17,36 \\
\hline 387 & 100 & 3,87 & 4,61 & 17,59 \\
\hline 398 & 100 & 3,98 & 4,74 & 18,09 \\
\hline TOTAL & & 84,03 & & 381,95 \\
\hline $\begin{array}{l}\text { RATA - } \\
\text { RATA }\end{array}$ & & 3,82 & & \\
\hline
\end{tabular}

Berikut ini merupakan pembahasan dan contoh perhitungan dari customer statisfaction index (CSI) yang dapat dilihat di tabel 4.11 Hasil Perhitungan Customer Statisfaction Index (CSI), yaitu :

1. Menentukan Mean Importance Score (MIS) atau rata-rata skor pentingnya. Nilai ini berasal dari rata-rata kepentingan tiap konsumen.

MIS $=\frac{359}{100}=3,59$

2. Menentukan Weighting Factor (WF), yaitu mengubah nilai rata-rata kepentingan menjadi angka persentase dari total rata-rata tingkat kepentingan seluruh atribut yang diuji, sehingga didapatkan total WF sebesar $100 \%$.

$\mathrm{WF}=\frac{3,59}{84,03} X 100 \%=4,27 \%$

3. Menentukan Mean Satisfaction Score (MSS) tiap variabel, yaitu dengan menggunakan rumus sebagai berikut :

$$
\operatorname{MSS}=\frac{84,03}{22}=3,82
$$

4. Menentukan Weight Score (WS), yaitu menilai perkalian antara nilai rata-rata tingkat kepuasan masing-masing atribut dengan WF masing-masing atribut.

$$
\mathrm{WS}_{\mathrm{i}}=\mathrm{WF}_{\mathrm{i}} \mathrm{x} \mathrm{MSS}
$$




$$
\begin{aligned}
\mathrm{WS} & =4,27 \% \times 3,82 \\
& =16,32 \%
\end{aligned}
$$

5. Menentukan Customer Statisfaction Index

$$
\begin{aligned}
\text { CSI } & =\frac{\text { Total Nilai } W S}{H S} \\
\text { CSI } & =\frac{381,95}{5}=76,39
\end{aligned}
$$

Pada umumnya, bila nilai CSI diatas 50\% maka dapat dikatakan bahwa pengguna jasa sudah merasa puas sebaliknya bila nilai CSI dibawah $50 \%$ pengguna jasa belum dikatakan puas. Nilai CSI di dalam penelitian ini terbagi menjadi 5 kriteria dari yang tidak puas sampai dengan sangat puas seperti yang ada pada tabel dibawah ini.

Tabel 4 Kriteria CSI

\begin{tabular}{|c|c|c|}
\hline No & Nilai CSI & Kriteria CSI \\
\hline 1. & $\mathrm{X}>0,81$ & Sangat Puas \\
\hline 2. & $0,66-0,80$ & Puas \\
\hline 3. & $0,51-0,65$ & Cukup Puas \\
\hline 4. & $0,35-0,50$ & Kurang Puas \\
\hline 5. & $0,00-0,34$ & Tidak Puas \\
\hline
\end{tabular}

Berdasarkan hasil perhitungan dari customer satisfaction index (CSI) mengenai kualitas pelayanan berdasarkan persepsi konsumen diblenger burger, yaitu sebesar 76,39 dimana nilai tersebut menunjukkan menurut kriteria nilai customer statisfaction index (CSI) adalah puas. Berdasarkan hasil perhitungan menurut ciustomer statisfaction index (CSI) menunjukkan bahwa tingkat kepuasan konsumen terhadap kualitas pelayanan diblenger burger sebesar 76,39 yang memiliki arti puas. Menurut kriteria nilai berdasarkan customer statisfaction index (CSI) untuk mencapai nilai dengan kriteria $>0,81$ tentunya blenger burger harus meningkatkan kualitas pelayanannya di dalam pelayanannya dengan cara meningkatkan kinerja dari karyawannya atas ketanggappan karyawannya dalam melayani konsumen diblenger burger. Berdasarkan hasil dari importance performance analysis atribut yang diprioritaskan terdapat pada atribut 14 dalam pernyataan mengenai "ketanggapan pelayan terhadap konsumen" oleh karena itu restoran perlu meningkatkan ketanggappan pelayannya terhadap konsumen dengan meningkatkan kinerja dari karyawan yang terdapat diblenger burger.

\section{Kesimpulan}

Kesimpulan dari hasil penelitian ini yaitu tingkat kualitas pelayanan diblenger burger terhadap kepuasan konsumen berdasarkan lima dimensi kualitas pelayanan, yaitu : tangible memiliki nilai gap sebesar $-0,66$, realibility memiliki nilai gap sebesar $-0,61$, responsiveness memiliki nilai gap sebesar -0,66, empathy memiliki nilai gap sebesar -0,58, dan assurance memiliki nilai gap sebesar -0,58. Berdasarkan hasil perhitungan dari customer satisfaction index (CSI) mengenai kualitas pelayanan berdasarkan persepsi konsumen diblenger burger, yaitu sebesar 76,39 dimana nilai tersebut menunjukkan menurut kriteria nilai customer statisfaction index (CSI) adalah puas.

\section{Daftar Pustaka}


Jurnal SEOI - Fakultas Teknik Universitas Sahid Jakarta

Vol 3 edisi 2 tahun 2021

Ariani, Wahyu Dorotea. (2004). Pengendalian Kualitas Statistik (Pendekatan Kuantitatif dalam Manajemen Kualitas). Yogyakarta.

Aritonang, R. L. (2005). Kepuasan Pelanggan. Jakarta : PT. Gramedia Pustaka Utama. Jakarta.

Barry Render, Heizer \& Jay. (2010). Manajemen Operasi. Edisi Ketujuh Buku 1. Jakarta: Salemba Empat.

Ghozali, Imam. (2011). Aplikasi Analisis Multivariate Dengan Program SPSS. Semarang: Badan Penerbit Universitas Diponegoro.

Irawan, Handi. (2009). 10 Prinsip Kepuasan Pelanggan. Jakarta : Elek Media Komputindo

Kartika Sukmawati. (2011). Pengaruh Kualitas Layanan, harga Dan Kepuasan Pelanggan Terhadap Loyalitas Pelanggan jasa Transportasi Kreta Api Ekskutif. Skripsi.

Kotler, Philip dan Kevin Lane Keller. (2009). Manajemen Pemasaran Buku 1. Jakarta : Erlangga.

Kotler, Philip. Amstrong Gary. (2014). Principles Of Marketing, 15 th Ed, Global Edition Pearson Education, New Jersey.

Lupiyoadi, Rambat. (2013). Manajemen Pemasaran Jasa Berbasis Kompetensi (Edisi 3). Jakarta : Salemba Empat.

Ninemeier, Jack D \& Hayes, David K. (2011). Restaurant Operations Management. New Jersey : Pearson Prentice Hall.

Purnomo, Hari. (2008). Pengantar Teknik Industri. Edisi Kedua. Jakarta : Graha Ilmu.

Rangkuti, Freddy. (2011). Strategi Promosi Yang Kreatif dan Analisis Kasus Integrated Marketing Communication. Jakarta : PT. Gramedia Pustaka Utama.

Sugiyono, Prof., Dr.(2012). Metode Penelitian Kuantitatif Kualitatif dan R\&D. CV. Bandung : Alfabeta

Tjiptono, F. (2014). Strategi Pemasaran Jasa. Yogyakarta : CV Andi offset.

Tjiptono, F., dan Gregorius, C. 2011. Service, Quality \& Satisfaction (Edisi 3). Yogyakarta : CV ANDI Offset.

Yamit, Zulian. (2011). Manajemen Produksi \& Operasi (Edisi Pertama). Yogyakarta : Ekonisia. 